\title{
Exploratory Practice: A way forward to getting the students back in the modern foreign language classroom
}

\author{
Assia Slimani-Rolls, Regent's University London, United Kingdom \\ Recepción: 15/07/2018 | Aceptado: 05/04/2019 \\ Correspondencia a través de ORCID: Assia Slimani-Rolls \\ (iD) $0000-0003-4136-1462$ \\ Citar: Slimani-Rolls, A (2019). Exploratory Practice: A way forward to getting the students back in \\ the modern foreign language classroom. ReiDoCrea - Monográfico sobre Perspectivas \\ transnacionales en la enseñanza de lenguas, 8(3), 19-29.
}

\begin{abstract}
This paper highlights some of the issues, which make it important to understand why calls for new trends of language teaching are omnipresent in the field of modern foreign languages (MFLs). These issues are, at least in the UK, the spread of English against the backdrop of globalization and its impact on the take up of MFLs, unhelpful language policies, lack of motivation on the part of English students to learn MFLs, the need for improving teacher training and language curricular, in general, across the sector. It is in the light of these issues that this paper proposes Exploratory Practice (EP), an innovative and inclusive form of practitioner research as continuing professional development (CPD) to empower teachers and learners to develop a better understanding of their practice and take it forward to meet their expectations and those of their learners.
\end{abstract}

Key words: Exploratory Practice

Práctica exploratoria: El camino a seguir para hacer que los estudiantes vuelvan a las clases de idiomas modernos

Resumen: Este artículo pretende exponer algunos de los aspectos que explican por qué la necesidad de encontrar nuevas tendencias es omnipresente en el campo de la enseñanza. Estos aspectos abarcan, al menos en el Reino Unido, el crecimiento del inglés con el trasfondo de la globalización y el impacto que esto ha tenido en la enseñanza de otros idiomas, las políticas poco favorables a la enseñanza de lenguas extranjeras y la falta de motivación de los estudiantes ingleses para aprender otras lenguas. A esto hay que sumar la necesidad de mejorar la formación de los docentes y la manera de enfocar la enseñanza de idiomas extranjeros en el currículo escolar en todo el sector. A la vista de todo lo anterior, esta ponencia propone la Práctica Exploratoria, una forma de investigación profesional innovadora e integradora, como alternativa de formación continua del docente que permite tanto a profesores como a estudiantes profundizar en la práctica docente para poder llegar a una mejor comprensión que les permita avanzar para cumplir sus expectativas

Palabras clave: Práctica exploratoria

\section{Introduction}

Calls for new trends in the teaching of modern foreign languages (MFLs) are overwhelmingly present in a climate where the uptake of MFL learning is in decline in the UK and elsewhere (Graddol 2006). This paper proposes to briefly review some of the factors that have let down the development of national foreign language competence in the UK such as (i) the impact that the relentless spread of English has had on the uptake of MFLs; (ii) the role that policy making has played in hindering their uptake; (iii) the characteristic lack of motivation of English language learners; and (iv) the call for improving MFL teaching curricula and teacher training programmers across the sector. The literature which relates to many of these issues seems to call for classroom working conditions that Exploratory Practice (EP), a form of practitioner research, puts forward in order to empower teachers and learners to develop a better understanding of their classroom practice. Hence, the first part of this paper provides a brief review of the issues which hinder the development of MFLs. The second introduces the principled framework of EP, illustrates how it works in the classroom and how it views the learners as partners 
in the learning and teaching enterprise in order to transform their language learning experience.

\section{The impact of the spread of English as a lingua franca}

Undoubtedly, the relentless spread of English as a lingua franca has impacted on the interest that is shown to MFLs in the UK as well as many other countries around the globe. In Northern Europe, Finland is referred to as 'little England' and is the favourite place after the UK for students to go on an exchange programme because of the extent to which English is spoken in this country (Coleman 2006: 6). In Sweden, Denmark, and Netherlands, close to $80 \%$ of the population claim to be able to converse in English. In Italy, Spain, Greece, and Portugal, employees and students are expected to operate in English. France has also joined the race for teaching English across the schooling system (Graddol 2006; Graddol 2004). In all of these countries, English is used as the medium of instruction (EMI) in parts of their higher education system in spite of some 'predictable problems' (Coleman 2006: 6) regarding need for more resources and teacher training, amongst others. In Asian countries such as China and Japan, policymaking has made English a foreign language that is taught in primary and secondary sectors as well as adopting it as a teaching medium in higher education for many of their taught subjects. Similarly, the profile of English is as high in the Middle East where it has, in some instances, displaced French in the primary and secondary sectors and is used in the STEM subjects (Science, Technology, Engineering, Mathematics) in the tertiary sector of many Arab countries (AL Bakri 2017). English is nowadays seriously challenging the status of French, which has, for decades, dominated the political, economic, social and cultural arenas of countries in North Africa (Benrabah 2013). Against this background, the demand for MFL is in a steady decline in the UK.

\section{English students' lack of motivation to learn languages}

In view of the above brief mention of the impact of the spread of English, it is not surprising that, as Howard (2017) contends, 'apathy has arguably become a prominent hallmark of MFL learning in the UK' (p. 34) and public opinion, in general, is indifferent to language learning. While Erler and Macaro (2011) estimate that 'motivation for L2 learning in England, particularly among young adolescents, is low' (p. 496), Ellis (2008) acknowledges motivation as 'the major determining success in L2 learning' ( $p .75)$. In the search for finding out what motivates adolescent language learners, Howard (2017) hypothesises that L2 motivation can be heightened through a social constructivist model of learning and teaching. This model considers the social context as crucial, given that 'learner construction of knowledge is the product of social interaction, interpretation and understanding' (Vygostky 1962). In the case of the classroom, the learners construct their knowledge in collaboration and dialogue with other participants, both peers and teachers.

According to Oxford (1997), 'social constructivism is the foundation for collaborative learning in the L2 classroom (p. 449). Regarding the impact of a social constructivist learning setting on students' L2 motivation, Dörnyei (1997) proposes that 'cooperative learning tends to produce a group structure and a motivational basis that provide excellent conditions for L2 learning' (p. 491). Following a series of quotes from advocates of collaborative learning that highlight the benefits of social activity in the classroom (Ning and Hornby 2014, Pritchard and Woodward 2013, Dörnyei 2003, Slavin 2000), Howard advises that in order to bring the students back to the MLF classroom, 'researchers and teachers need to decipher the true motives of adolescent learners and adapt L2 language pedagogy' (p.39). It is interesting to note that although Howard advocates a social constructivist model, she does not include the learners in the investigation of this 
correlation between motivation and collaboration where the learners normally play a significant role. As we shall see below, Exploratory Practice considers the learners as 'key developing practitioners' (Allwright and Hanks 2009: 2) and include them in the search for understanding as learners are an integral part of the classroom environment. The authors explain that given that the field of language teaching readily accepts teachers as responsible for teaching, "why not try to think of learners as practitioners of learning and not just as 'targets of teaching' (p.2) and research. After all it is the learners that are assumed to do the learning from the adapted L2 language pedagogy arranged by the teachers and researcher.

Hanks (2017: 49) illustrates further the necessity for learner inclusivity in the search for understanding by referring to Freire's work on developing literacy in the Brazilian countryside $(1970,1973)$. Freire argues against the idea of an outsider coming in to tell the workers why and how they should develop literacy. He considers education as an endless two directional flow of exchanges between the learners and those who attempt to facilitate the learning. Hanks refers also to the field of psychotherapy whereby Casement (1985) highlights opportunities for analysts to engage in dialogue with patients in order to learn from them: 'Opportunities for learning from the patient are there in all caring professions. [...] I hope [...] that those in allied caring professions will be able to play with the ideas I explore here and to relate them to their own spheres of work' (p. xii). As we shall show below, learners are capable of taking learning seriously and capable of independent decision-making (Allwright and Hanks 2009: 6-7). Nevertheless, and more often than not, the learners' position in educational settings seems to be ignored by policy makers, researchers and teachers who tend to see them mostly as targets for teaching and research rather than key developing practitioners.

\section{MFL policy making in the UK}

Aside from the impact of English as a global language and English students' lack of motivation as seen above, policy making in the UK bears the blame for the decline of MFL learning. Indeed, Lanvers and Coleman (2017) explain that "in 2004, under a labour government, compulsory language learning Key Stage 4 students (typically aged 14-16) was abolished in England, a decision widely viewed as contributing to a substantial fall in the number of students studying a language up to GCSE" (p.4). A downturn from $40 \%$ of Year 11 pupils in 2011 taking an MLF as opposed to 78\% in 2001 has been reported (Malpass (2014:3). Not only has this policy thwarted the growth of MFL learning in high schools, it has also severely limited the university entry of MFL student specialists who normally ensure the future of MFL teaching to other generations of learners. In other words, the removal of compulsory languages at Key stage 4 has had a domino effect on the take up of languages. 'No post-16 pupils, so no graduates, so no teachers' as put by Swarbick (2002: 12). For further discussion, see also Watts 2004, Patchler 2002.

It is interesting to note that Macaro (2008) argues differently the reasons that led to the decline of MFLs. He contends that "the optional nature of MFLs does not necessarily lead to their decline, in fact, the very opposite may be true" (p.101). Macaro goes back in time to attribute this slump of MFL uptake to the introduction of the National Curriculum and Languages for All policy in 1992. These events were followed in 1993 by a drop of half of the A level entries for French and German. Macaro relates this historical downturn to two main reasons. The first reason is pinned on the National Curriculum which strongly recommended that the target language (TL) is exclusively used in the classroom (DES 1990: 58). This recommendation has, according to Macaro, 'led to massive feelings of guilt from teachers, and growing exasperation from students" (p.104). This reaction was, presumably, due to teachers' lack of confidence to interact, at all times, in the TL and to students' inability to follow and contribute to the classroom events exclusively in the 
same language. The second reason is related to the students being, in actual fact, forced to take up a language that they do not enjoy or see its learning as relevant to their circumstances. At the same time, both French and German, which were imposed upon the students, were losing their international status.

Macaro believes that it is the combination of these elements - the loss of MFL prestige, the teachers' disapproval of 'a diktat being imposed on them' ( $p .104)$ and the burden of uncooperative 14 year old learners being 'forced to learn a language' ( $p .106)$ - that is more likely to have been responsible for disparaging, both teachers and learners, from committing to developing MFL competence. In other words, Macaro estimates that interfering with the languages that teachers use to mediate the socio-emotional climate of the classroom and the infinite ways of managing decision-making processes as well as interfering with the learners' personal choice of language to contribute to the classroom events have actually had a devastating effect on teachers and learners wanting to remain in the language classroom. Indeed, the scenario of simply ignoring the learners' views is somewhat reminiscent of the Swedish students' situation. CabauLampa (2007) explains that 'the problem in Sweden is that all the parties interested in FLT (foreign language teaching) want it to be reinforced, except those primarily concerned, i.e. the learners. The latter have made their choice: to put priority on English learning' (p. 352). Indeed, as a result of ignoring the learners' wishes, English has grown today to be the second language in Sweden and even constitutes a threat for Swedish to remain a national language. If anything, this example shows that the learners' views are not to be underestimated. If students are to embrace language learning then there is a need to involve them, talk to them (Coleman 2007) and engage in collaboration with them, not in spite of them.

\section{Calls for developing better teaching curricula, teacher training and CPD}

This paper considers Exploratory Practice (EP) within the longstanding decline in foreign language competence in education and continuous employer demand for better language skills; thus, leading the UK to rethink their language policy for the $21^{\text {st }}$ century. Various language surveys from government bodies and academic institutions have identified deficiencies in MFL learning and evidence of weaknesses in teaching and curricula across the primary, secondary and tertiary sectors as well as in life-long learning programmes (Holmes 2014). English is no longer accepted to be enough to work effectively with the rest of the global community and calls are made to create more conducive environments to embrace learning. Watt (2004) highlights the 'urgent need for properly trained quality language teachers to deliver a coherent modern foreign language syllabus starting in the primary school sector and continuing throughout the education system' (p. 66). Pauwels (2011) deplores the lack of research-informed teaching and inadequacy of language curricula in higher education. Marsden and Kasprowicz (2017); Macaro, Graham and Woore (2016); and Macaro (2003) call upon MFL teachers to engage in research to create for themselves opportunities for professional development.

The rest of the paper presents Exploratory Practice (EP) as an innovative way for teachers and their learners to develop themselves and transform their classroom for their mutual benefit. 


\section{Exploratory Practice (EP): The way forward for learners and teachers in the MFL classroom}

Over the last four decades or so, much has been said to encourage language teachers to engage in research as a contributing factor to teachers' professional development (Macaro, Graham and Woore 2016; Macaro 2003; Zeichner and Noffke 2001; CochranSmith and Lytle 1993; Stenhouse 1985). However, the literature indicates that little research, if any, has been carried out by teachers in English language teaching (Borg 2013, 2010, 2009) and modern foreign languages (Marsden and Kasprowicz 2017) to cite only these scholars. The reasons behind this lack of engagement in research is well documented (Hanks 2017; Abbott, Rossiter, and Hatami 2015; Borg 2010: 409). However, suffice it to say for the purposes of this paper, that the lack of time, access to research, little expert support, and lack of research skills have played a major part in limiting teachers' engagement with research. In this respect, Exploratory Practice (EP), a form of inclusive practitioner research designed in the 1990s has been put forward in order to empower teachers and learners to develop a better understanding of their classroom practice (Allwright and Bailey 1991; Allwright and Lenzuen 1997). EP's theoretical framework is defined by several distinctive principles whose aims are to guide teachers and learners to elucidate teaching puzzles that the classroom participants have encountered in their learning and teaching environment. For instance, 'Why aren't the students interested in my teaching?' (Slimani-Rolls and Kiely 2014), 'why doesn't group work proceed the way I organise it?' (Slimani-Rolls 2003) and 'why do students use so much their mother tongue in the classroom (Rawson 2018). For more teacher and learner puzzles, see Dikilitas and Hanks 2018, Slimani-Rolls and Kiely 2018, and Allwright and Hanks 2009.

EP's guiding principles are as follow:

1. 'Quality of life' for language teachers and learners is the most appropriate central concern for practitioner research in our field.

2. Working primarily to understand the 'quality of life', as it is experienced by language learners and teachers, is more important than, and logically prior to, seeking in any way to improve it.

3. Everybody needs to be involved in the work for understanding.

4. The work needs to serve to bring people together.

5. The work needs to be conducted in a spirit of mutual development.

6. Working for understanding is necessarily a continuous enterprise.

7. Integrating the work for understanding fully into existing curricular practices is a way of minimising the burden and maximising sustainability.

a. (Allwright and Hanks 2009, p. 149-154)

Principles 1 and 2: Quality of life is given priority because the search for understanding the learning and teaching environment is, first and foremost, motivated by the need to establish a quality of life that is suitable for the participants of the classroom setting. EP believes that it is the quality of life that opens the way to the quality of work (Gieve and Miller 2006). When the classroom environment is seen to be constructive and positive by learners and teachers alike, they are likely to be more inclined to invest themselves in order to contribute to their growth and that of the classroom community. As reported above, Macaro (2008) argued that the disinterest in MFLs grew out of the teachers' being denied the language choice to manage the infinite classroom decision-making processes which often emerge independently of any prior planning. This disinterest is also contended to be part of a sweeping blanket policy upon the learners to interact entirely in a language that they have not yet mastered. Surely such externally imposed decisions are bound to impact negatively on the quality of life of the classroom participants. They, 
alone, live these classroom events and ought, as such, to be trusted to handle them in the moment as they see fit in their immediate and evolving circumstances.

Exploring the strategies that 14-year-old learners use for speaking German, GallagherBrett (2007) reported that the learners highlighted their reluctance to speak in class and have identified, unsurprisingly, 'practice' and 'revision' as their favourite strategies. She explains that this situation seems to be related to high levels of anxiety and lack of confidence when speaking and prefer to rehearse language and situations with which they are most familiar. Forcing them therefore to interact would neither make their quality of life better nor their language learning experience more productive in the classroom. In this respect, observing lessons whose pedagogy was focussed on fun activities using visuals, DVDs, games, songs and such like, have led Cable, Driscoll, Mitchell, and Sing (2010) to remark some improvement in language learning after special efforts have been made by the research team and the teachers to avoid much formal assessment, as is often the case in core National Curriculum subjects, in order to avoid undermining the 'fun' aspect of language learning. In the same school where Cable et al. three year-long study was conducted, the researchers noted that the attitude of the teachers was also focussed on promoting an international value of languages within the school, creating space for intercultural learning and helping children to build up confidence in speaking and listening across the curriculum. Commenting upon this study, Mitchell (2011) agrees that a more process-oriented approach to language education can, indeed, lead to enhanced and sustained motivation as well as enable learners to be more confident.

Principles 3, 4 and 5 are geared towards developing collegiality so as to bring together all those who can benefit from the task of building up a better understanding of the language learning and teaching environment and work together for the mutual advancement of all the participants involved in the search for understanding. As Allwright and Hanks (2009) elaborate "One of the main planks of EP is collegiality - learners and teachers [other practitioners] working together to investigate what puzzles them and to share their findings in their local context" (p. 186). These principles emerged as a reaction to the parasitic conduct of traditional researchers who enter the classroom with the aim of collecting data so as to develop their understanding without returning to share it with the teachers and learners who constituted the site of their data collection.

Whorton's review (2009) of the health of MFL teaching in higher education casts light on the absence of collegiality in the divisive situation prevailing between language teachers working in language centres and institution wide language programmes (IWLPs) on the one hand, and university academics working in language departments on the other. The former, are confined to teaching in language centres and IWLPs with no prospects of engaging in research in spite of the fact that many have MAs and some Ph.Ds. (Campbell et al. 2015-2016). The latter relegates the teaching of languages to mostly untrained language assistants and they teach content subjects essentially in English, as we shall see below, to the detriment of their students' MFL competence. Moreover, their research is generally unrelated to pedagogy and language teacher education which are essentially deemed to be developed at university level. In this respect, Gieve and Conico (2012) conclude their study by referring to Exploratory Practice and advising university academics to work together with and listen to their students who requested that the teaching of their content subjects to be carried out in the foreign language given that one of their aims of taking up a language degree is to learn to speak fluently the target language. Similarly, McBride (2003) states in her study about the role of the target language in cultural studies in UK universities that 'it is crucial both for higher education lecturers and for curriculum planners in language departments to listen to the students' voice' (p. 310). Indeed, here again the students are vocal about the necessity of receiving knowledge and understanding about their specialism in the target language that they have chosen to study. As advocated by Allwright and Hanks (2009), learners should be 
seen as practitioners of learning just as teachers are seen as practitioners of teaching. Learners are knowledgeable about what is best for their own learning and teaching environment.

As Rawson and some of her colleagues (2018) learned, when using the principled framework of EP in their classrooms, it is worth taking into consideration the learners' perspectives. Rawson was set in her views that there is greater value in communicating in the target language only as she was instructed, in the teacher training programme that she undertook many years ago. However, following group discussions with her students and their various responses to a study of a comprehension text about the use or otherwise of the mother tongue in the classroom, Rawson found that the students' views of being allowed to use the mother tongue in special circumstances correlated with those of other academics (White 2001, Atkinson 1987). Most of the students insisted all along that ideally, the target language should primarily be used during the class except, however, when the mother tongue is 'used sporadically ... for translation and clarification purposes' (p. 95) so they do not feel frustrated or that they are wasting their time. It is clear that Rawson's students are undergraduates majoring in Business and Management Studies while Gieve's and Conico's as well as McBride's are specialist language students thus requiring different levels of use of the target language in the classroom. However, it is interesting to see that the students do actually understand what it is that they need for their learning experience to be a positive one.

Principles 6 and 7 are meant to empower teachers to develop their understanding of their pedagogies as these constitute an integral part of their work in the classroom. Given that teachers have neither the time nor the skills to engage in research in the same way academic researchers do, EP affords them the possibility of integrating the search for understanding in their everyday teaching routine by using familiar and normal classroom activities as investigative tools. In this way, the teacher's research activity becomes an integral part of teaching and not extra to it in order to make research sustainable. These research tools can be diaries that Chu (2012), for instance, used for her doctoral work while still carrying on with the regular routine of teaching her classes; discussion of research papers that Rowland (2007) adopted with his MA and MSc students on an English for Academic Purposes programme; brainstorming sessions and classroom discussions (2003) as well as pair work and group work (2005) that Slimani-Rolls employed with her undergraduate students learning French as a foreign language in a Business and Management Studies programme, or interviews that Gunn (2003) used with her secondary school students to investigate the development of their communicative language competence. Gunn asked her students to interview local teachers for two or three minutes. This operation was integrated in the normal teaching routine that involved Gunn and her learners to work on their language development. A whole set of learning exercises were developed from these interviews to create a series of data in order to investigate the development of her learners' communicative competence: the learners wrote up the interview questions, the invitation letters for the interviewees, the thank you letters for those who accepted to be interviewed as well as carry out their transcription. This work took place during class time with the teacher moving around the students helping them with their language use i.e., spelling,, lexis and grammar while, at the same time, taking account of the progress and/or difficulties that the students encountered. Hence, EP is deemed primarily to be a way of getting teaching and learning done, rather than a way of getting research done. See also Hanks 2017 about the development of EP over the last two and a half decades and the use of its theoretical framework for teaching and research purposes across the education sector in various geographic regions throughout the world. See also the work that is being carried out by the International Association of Teachers of English as a Foreign Language (IATEFL) Research Special Interest Group (ReSIG) to enable teachers to 
make their research public in ways that are doable by teachers (Etherington and Daubney 2017; Bullock and Smith 2015).

\section{Conclusion}

This paper has brought together some of the factors that have contributed to the demobilisation of learning of modern foreign languages in the UK where policy makers, researchers and practitioners may feel as if they are 'still gardening in the gale' (Mitchell 2011). This paper has also put forward an innovative way to enable teachers to bring students back to the classroom by transforming their pedagogies through the use of the principles of Exploratory Practice which have been presented above namely prioritising quality of life, search for understanding, collegiality for mutual development, learner inclusivity in the research enterprise and research sustainability through the use of normal classroom activities - as the driving forces that keep teachers and their learners on the task of understanding better their practice. These principles are believed to have maintained Rawson (2018) and others mentioned above in order to maintain their investigative efforts to understand their puzzles which ultimately enabled them to access a wealth of personal, professional and social development.

\section{References}

Abbott, M. L., Rossiter, M. J., \& Hatami, S. (2015). Promoting engagement with peerreviewed journal articles in adult ESL programs. TESL Canada, Journal, Revue TESL du Canada, 33, 80-105.

Al-Bakri, S. (2017). Effects of English medium on students' learning experiences and quality of education in content courses in a public in Oman. Unpublished PhD thesis. Graduate School of Education. University of Exeter.

Allwright, D. (2003). Exploratory practice: Rethinking practitioner research in language teaching. Language Teaching Research, 7(2), 113-141.

Allwright, D., \& Bailey, K. M. (1991). Focus on the language classroom. An introduction to classroom research for language teachers. Cambridge, New York and Port Chester: Cambridge University Press.

Allwright, D., \& Hanks, J. (2009). The developing language learner. An intro- duction to Exploratory Practice. Basingstoke: Palgrave Macmillan.

Allwright., D., \& Lenzuen, R. (1997). Exploratory practice. Work at the Cultura Inglesa, Rio de Janeiro, Brazil. Language Teacher Research, 1(1), 73-79.

Atkinson, D. (1987). The mother tongue in the classroom: A neglected resource? ELT Journal, 41(4), 241-247.

Benrabah, M. (2013). Language conflict in Algeria from colonialism to postindependence. Bristol, Buffalo, Toronto: Multilingual Matters.

Borg, S. (2009). English language teachers' conceptions of research. Applied Linguistics, 30(3), 358-388.

Borg, S. (2010). Language teacher research engagement. Language Teaching, 43(4), 391-429. 
Borg, S. (2013). Teacher research in language teaching. A critical analysis. Cambridge: Cambridge University Press.

Bullock, D., \& Smith, R. (2015). Teacher research! Faversham: IATEFL

Cabau-Lampa, B. (2007). Mother tongue plus two European languages in Sweden: Unrealistic educational goal? Language Policy 6:333-358.

Cable. C., P. Driscoll., R. Mitchell., \& Sing. S. (2010). Language Learning at Key Stage 2: A Longitudinal Study. London: Department for Children Schools and families.

Campbell, C., Cirillo, C., \& Critchley, M. (2015-2016, March). UCML-AULC survey of institution-wide language provision in universities in the uk> http://www.ucl.ac.uk/languages-education/he-languages. Accessed 8 July July 2018.

Chu, P. (2012). How students seek for realisation through Exploratory Practice. A journey of growing together. Unpublished doctoral dissertation, Department of Education. University of Leicester.

Cochran-Smith, M., \& Lytle, S. (1993). Inside/outside: Teacher research and knowledge. New York: Teachers College Press.

Coleman, J. A. (2006). English-medium teaching in European higher education. Language Teaching, 39, 1-14.

Coleman, J. A., A. Galaczi \& Astruc, L. (2007). Motivation of UK school pupils towards foreign languages: a large-scale survey at key Stage 3". Language Learning Journal (35) 245-280.

Cook, V. (2001). Using the first language in the classroom. Canadian Modern Language Review, 57(3), 402-423. DOI 10.1007/s10993-007-9055-6

Dörnyei, Z. (1997). Psychological processes in cooperative language learning: Group dynamics and motivation, Modern Language Journal, 81:482-493.

Dörnyei, Z. \& (2003). Attitudes, orientations, and motivations in language learning: Advances in theory, research, and applications, in Z. Dörnyei (ed.) Attitudes, orientations and motivations in language learning. Oxford: Blackwell, pp.3-32.

Dörnyei, Z. \& Schmidt, R. (eds.) (2001). Motivation and Second Language Acquisition, Nati Foreign Language Resource Center.

Dörnyei, Z. \& Skehan, P. (2003). Individual differences in second language learning, in C.J. Doughty, \& M.H. Long (eds.), The handbook of second language acquisition, Oxford: Blackwell, pp.589-630.

Ellis, R. (2008). The Study of Second Language Acquisition ( $2^{\text {nd }}$ edition), Oxford: Oxford University Press.

Erler, L. \& Macaro, E. (2011). Decoding ability in French as a foreign language and language learning motivation, Modern Language Journal, 95 (4), 496-518 
Etherington, S., \& Daubney, M. (2017). Developing helping as an EFL researcher: Stories from the field. Faversham: IATEFL.

Gallagher-Brett, A. (2007): What do learners' beliefs about speaking reveal about their awareness of learning strategies? Language Learning Journal, 35, 37-50.

Gieve, S., \& Conico, S. (2012). Language and content in the modern foreign language degree: A students' perspective. The Language Learning Journal, 40(3), 273291).

Gieve, S., \& Miller, I. K. (Eds.). (2006). Understanding the language classroom. Basingstoke: Palgrave Macmillan.

Graddol, D. (2004). The future of language. Science, 303, 1329-1331.

Graddol, D. (2006). English next. London: The British Council

Gunn, C. (2003). Exploring second language communicative competence. Language Teacher Research, 9(2), 241-259.

Hanks, J. (2017). Exploratory Practice in language teaching. Puzzling about principles and practices. Basingstoke: Palgrave Macmillan.

Holmes, B. (2014). Born Global. British Academy. http://www.britac.ac.uk/policy/Born Global.cfm Consulted in October 2018.

Howards, K. (2017). A critical study of motivation and social constructivism in the modern foreign languages classroom'. The STeP Journal, 4(3), pp.34-41

Lanvers, U., \& Coleman, J. A. (2017). The UK language learning crisis in the public media: a critical analysis. In the Language Learning Journal, 45:1, 3-25, DOI: 10.1080/09571736.2013.830639.

Macaro, E. (2003). Second language teachers as second language researchers. Language Learning Journal, 27(1), 43-51.

Macaro, E. (2008). The decline in language learning in England: getting the facts right and getting real. The Language Learning Journal, 36:1, 101-108, DOI:10.1080/0957173081988595

Macaro, E., Graham, S., \& Woore, R. (2016). Improving foreign language teaching: Towards a research-based curriculum and pedagogy. London and New York: Routledge.

Marsden, E., \& Kasprowicz, R. (2017). Foreign language educators' exposure to research: Reported experiences, exposure via citations, and a proposal for action. The Modern Language Journal, 17, 1-30. https://doi.org/10.1111/ modl.12426.

McBride, N. (2003). The role of the target language in cultural studies: Two surveys in UK universities. Language, Culture and Curriculum, 16:3, 298-311. 
Oxford, R (1997). Cooperative Learning, Collaborative Learning, and Interaction: Three communicative Strands in the Language Classroom, The Modern Language Journal, 84 (4), 443-456.

Patchler, N. (2002). Foreign language learning in England in the twenty-first century. Language Learning Journal 25: 4-7.

Pauwels, A. (2011). Future directions for the learning of languages in universities: challenges and opportunities. Language Learning Journal. (39) 2, 247-257.

Pritchard, A. \& Woollard, J. (2013). Psychology in the Classroom: Constructivism and Social Learning, Oxford: Routledge.

Rawson, M. (2018). Using the mother tongue in the language classroom. In SlimaniRolls, A., \& R. Kiely. pp. 91-103.

Rowland, L. (2011). Lessons about learning: Comparing learner experiences with language research. Language Teaching Research, 15(2), 254-267.

Slavin, R. (2000). Educational Psychology: Theory and Practice, (6 ${ }^{\text {th }}$ edition) Boston, MA: Allyn and Bacon.

Slimani-Rolls, A. (2003). Exploring a world of paradoxes: An investigation of group work. Language Teacher Research, 7(2), 221-239.

Slimani-Rolls, A. (2005). Rethinking task-based language learning: what we can learn from the learners. Language Teacher Research, 9(2), 195-218.

Slimani-Rolls, A., \& Kiely, R. (2014). 'We are the change we seek': Developing teachers' understanding of their classroom practice. Innovations in Education and Teaching International, 51(4), 425-435.

Slimani-Rolls, A., \& Kiely.R (2018). Exploratory Practice for Continuing Professional Development: An Innovative Approach for Language Teachers. London. Palgrave Macmillan.

Stenhouse, L. (1985). Research as a basis for teaching. London: Heinemann Educational Books.

Swarbick, A. (ed.) (2002). Teaching modern foreign languages in secondary schools: A Reader. Abingdon: Routledge.

Vygostsky, E. (2012) [1962] Kozulin, A. (ed.). Thought and Language. Cambridge, MA: Massachusetts Institute of Technology.

Watts, C. (2004). Some reasons for the decline in numbers of MFL students at degree level. Language Learning Journal 29: 59-67.

Zeichner, K. M., \& Noffke, S.E. (2001). Practitioner research. In V. Richardson (Ed). Handbook of research on teaching (4th ed., pp. 298-330). Washington, DC: American Educational Research Association. 